\title{
TRANSCARPATHIA - UKRAINIAN BORDER REGION AT THE EDGE OF THE EU. INTERNAL AND EXTERNAL REPRESENTATIONS
}

\author{
Peter Jordan ${ }^{*}$ \\ *Austrian Academy of Sciences, Institute of Urban and Regional Research, Postgasse 7/4/2, A-1010 Wien, Austria, \\ peter.jordan@oeaw.ac.at
}

ICA Commission on Atlases

KEY WORDS: borderland studies, regional development, regional identity, post-Communist transformation

\begin{abstract}
:
Starting from 1918, multiethnic Transcarpathia changed after centuries of being an integrated part of Hungary frequently its political affiliation and is since 2004 a Ukrainian border region to the European Union. Three of the four European Union neighbour countries belong since 21.12.2007 to the Schengen zone (Poland, Slovakia, Hungary), only the southern neighbour Romania is for the time being not yet a Schengen country.

After a phase of relatively open borders and relatively intensive neighbourhood relations in the first transformation years, by the Schengen regime the situation for Transcarpathia changed again. The current situation, possibly still to be intensified by the Schengen entry of Romania, is likely to persist for some time.

What does this mean for Transcarpathia as well as for the wider region in the northeast of the Pannonian basin? Which factors are determining the development in Transcarpathia? Which position maintains Transcarpathia within the Ukraine, how does it look at Kiev and how is it looked at by Kiev and the cis-Carpathian areas of the Ukraine?

The paper deals under these aspects with economic development in Transcarpathia, the interest of foreign investors in the region, its role in the continental transportation network, the identity of the Slavonic population majority and regionalism, also with the position of the large Hungarian minority in the region and its relation to the motherland.

The paper is based on a larger research project completed and published already in 2004 (Peter Jordan, Mladen Klemenčić: Transcarpathia - Bridgehead or Periphery?), but adopts also the results of a later diploma work of a student of the author (Berenike Ecker) as well as results of more recent research by the author himself.

It is found that shaping by Hungarian history, borderland location and multiethnic structure can be defined as the essential components of Transcarpathian identity. Its economic potentials and perspectives rest mainly in richness in wood, its pleasant landscape and mineral waters, its location in the European traffic network, its border location and bridge function, the rich language skills of its population, the region's Central European character. By post-Communist industrialisation (wood processing, food industry, electrotechnical industry) and due to intense transborder relations of the Hungarian minority the region was able to make some progress during the transformation period, but could not yet escape its economically peripheric position. Major obstacles for a better development can be identified in an all but market-conform agriculture, in the Schengen regime cutting Transcarpathia off especially from Slovakia and Hungary as well as in Ukrainian regional governance structures enforcing centralist attitudes at the two levels of regional administration.
\end{abstract}

\section{INTRODUCTION}

This paper refers to the westernmost Ukrainian region [oblast'] Transcarpathia [Zakarpattja] ${ }^{1}$, separated from the rest of Ukraine by the Carpathians. The view from central Ukraine and Kiev [Kiìv] explains also the region's modern English exonym Transcarpathia.

The paper is based on an interdisciplinary scientific project lead by Mladen Klemenčić and the author of this contribution, sponsored by the Austrian National Bank and completed in 2003 (Jordan \& Klemenčić, 2004a), the diploma work of Berenike Ecker (2005) on the economic development of Transcarpathia with special regard to cross-border relations supervised by the author and the author's further research since.

The paper will try to present answers to the following questions:

- What makes Transcarpathia a special case among Ukrainian regions and what are the ingredients of its identity?

\footnotetext{
${ }^{1}$ Also Zakarpats 'ka oblast'
}

- Is this special position relevant for economic potentials and development perspectives?

- How have these potentials been used so far?

\section{COMPONENTS OF TRANSCARPATHIAN IDENTITY}

\subsection{Culturally shaped by long-lasting affiliation to Hungary}

From the initiation of a Hungarian state (around 1000) to 1918 and again during World War II (1938/39-1944) modern Transcarpathia formed an integrated part of Hungary. Only between the wars it was - known as Subcarpathian Rus' or Podkarpatská Rus' - a province of Czechoslovakia. ${ }^{2}$ Not before 1945 it was awarded to

\footnotetext{
${ }^{2}$ Other names for the region - not always exactly within the same borders - are Transcarpathian Ukraine [Zakarpats'ka Ukraina], Carpatho-Ukraine, Ruthenia [Rusinsko], Subcarpathia, (Hung.) Kárpátalja, Hungarian Ukraine, Hungarian Rus', Ugro-Rus', (Hung.) Ruténföld,
} 
Soviet Ukraine as a „present" for liberation by the Red Army.

This long-lasting adherence to Hungary had an impact also on non-Hungarian autochthonous groups. Local Ukrainians (the vast ethnic majority with a share of $80 \%$ ) feel to be different from Ukrainians on the other side of the Carpathians. They are so seen also from there, i.e. from West Ukraine, e.g. from L'vìv. While West Ukrainians conceive themselves to be the core group of the Ukrainian nation, they look at Ukrainians in Transcarpathia not anymore as Ukrainians in the proper sense.

The consciousness of Ukrainians in Transcarpathia goes indeed not in a few cases as far as to a national consciousness different from the Ukrainian: Many of them conceive themselves as Rusyns (see Bonkalo, 1990; Kocsis \& Kocsis-Hodosi 1998; Magocsi, 1978, 1999a, b, Panchuk, 1995). Ukrainians from outside the Carpathian arc, who had immigrated in the Soviet period, used to remain outsiders.

The at least regional, if not national identity of Transcarpathian Ukrainians is supported by the Greek-Catholic Church. This union with Rome, founded in 1646 in Ungvár [Užgorod] and called the Union of Ungvár, was to support the Pannonian Ukrainians' Western orienttation. ${ }^{3}$

The distinct regional consciousness of Transcarpathian Ukrainians expressed itself also by a regionalist movement in 1990 striving for autonomy and culminating in a referendum on autonomy (Dezember 1991) that received an overwhelming majority, but was not respected by Kiev.

Another specific of the region inherited from the times of Hungarian rule is the still vigorous position of the Hungarian language. It is not only cultivated by the Hungarian ethnic minority, but also spoken by other ethnic groups, especially by other minorities like Germans and Roma. For this reason it is frequently used as a trade language and for inter-ethnic communication.

Regional identity shaped by Hungarian history expresses itself also in political voting. Thus, in contrast to all other parts of Ukraine, the Ukrainian parliamentary elections 2007 saw in Transcarpathia a regional party as the winner.

Especially in the early 1990s Transcarpathian regionnalism was strong and frequently combined with a lack of loyality to modern Ukraine. In 1994, e.g. with an enquete conducted by the Global Security Program of the University of Cambridge UK on the question „To which country should Transcarpathia belong to?" only 52\% of the respondents supported the status quo, while $13 \%$ pleaded for Hungary, 9\% for Slovakia and 14\% for independence (Jordan \& Klemenčić 2004a, Fig. 23, p. 295). In the meantime regionalism has certainly calmed down, but can always be re-activated.

\subsection{A traditional borderland}

Under Hungarian rule modern Transcarpathia was a borderland towards Galicia [Galicja, Galičina]. In the interwar period it functioned as a Czechoslovakian

Rus'ka Krajna, Rusyn Land, Ruthenia. Marchia Ruthenorum, Subcarpathian Ruthenia, Carpatho-Ruthenia, Subcarpathian Russia, Carpatho-Russia.

${ }^{3}$ But also the Ukrainians in Galicia [Galicja, Galičina] were organized in a Greek-Catholic Church, the Union of Brest, founded even earlier (1596). Also this documents a Western cultural and political orientation of this group. outpost in the East (see Kozauer, 1964). After World War II until the early 1990s it was a strategic glacis of the Soviet Union in the Pannonian Basin (see Hokky, 1966; Němec \& Moudry, 1955). Today it is the Ukrainian bridgehead in the Pannonian Basin with borders to Poland, Slovakia, Hungary and Romania. Only in the Northeast and East it has boundaries with other Ukrainian regions (L'vìv and Ivano Frankivs'k).

This borderland function was always linked with the status of an economic periphery. As the thematic maps of Helmut Rumplers and Martin Segers Atlas of the Habsburg Monarchy 1848-1918 show (Rumpler \& Seger, 2010), the Hungarian counties roughly corresponding to what is today Transcarpathia (Bereg, Máramaros, Ugocsa) were according to most socio-economic indicators well behind the average of the Hungarian half of the Monarchy, which was anyway lagging behind most of the Austrian crown lands, especially the Bohemian Lands and Lower Austria [Niederösterreich] with the Empire's capital Vienna [Wien].

Also in the interwar period, Czechoslovakian "Subcarpathia" was by far the least developed province of this in fact rather artificial political construct composed of the highly developed, urbanised and industrialised provinces of Bohemia [Čechy] and Czech Silesia [Slezsko], the still well advanced, but more agrarian Moravia [Morava], the almost completely agrarian Slovakia [Slovensko] and the most backward Subcarpathia. This can clearly be seen in the so-called "Masaryk Atlas", published in 1935 (Česká akademie věd a uměni, 1935).

The Atlas of Danubian Countries (Breu, 1970-1989) proves that in spite of some efforts to industrialise the region (according to Communist principles) not very much has changed under Communist rule. Even compared to West Ukraine, Transcarpathia is in a backward position.

It is also a fact that none of the urban settlements in Transcarpathia succeed at any time to occupy a more prominent position in the central place system. Munkács [Mukačeve] achieved some importance as a fortress of the defence system along the eastern borders of Hungary, but not so much as an urban centre. Also Užgorod, modern Transcarpathia's capital, is not more than a lessequipped regional centre in the shadow of Košice (Slovakia) and Debrecen (Hungary).

\subsection{A multiethnic region}

Transcarpathia is a multiethnic region with an ethnic majority, which feels partly to be a nation of its own and a large and culturally strong minority. All data to be presented here are taken from the first all-Ukrainian census of 2001 (Deržavnyj komitet statystyky Ukraïni, 2003), information on the spatial distribution of the ethnic groups can be found especially in Kocsis, 1999; but also in Breu, 1989; Jordan \& Kocsis et al., 2006; Kocsis \& Kocsis-Hodosi, 1998, on Ukraine in total also in Jordan, Kappeler, Lukan \& Vogl, 2001.

$80.5 \%$ or one million Ukrainians are titled in this way by the census and were not allowed to declare themselves differently. But most of them call themselves Ruthenes or Rusyns. They are Eastern Slavs as the Ukrainians, but in contrast to them culturally shaped by the long Hungarian rule, by a very specific dialect, which could be called a 
language, but is not standardized ${ }^{4}$ and by their partly Orthodox, partly Greek-Catholic denomination.

The $12.1 \%$ or 152,000 Hungarians were by the end of the $17^{\text {th }}$ century the ethnic majority in the region and the dominating state nation up to 1918. They settle compactly in the Lowland nearby the Hungarian border, maintain a strong cultural identity and their language very well and are in close contact to Hungary at various levels: to relatives, by legal and illegal commuting across the border, which is relatively open for them (They are exempted from the strict border regime and have to present only an identity card.), by seasonal work in agriculture and construction in Hungary and by Hungarian investment in Transcarpathia (ca. 20\% of all foreign investment). Due to their contacts they are usually economically better off than average Transcarpathians.

The $2.6 \%$ or 32,000 Romanians settle in the region since the $13^{\text {th }}$ century (earlier called "Valachs") and settle compactly in a small area in the eastern part of Transcarpathia near to the Romanian border.

The $2.5 \%$ or 31,000 Russians are or descend mostly (from) immigrants in the interwar period and after 1945. They live mainly in cities and towns and suffered from significant remigration after 1992.

The $1.1 \%$ or 14,000 Roma are only this share of the by estimates up to 40,000 Roma, which declared their ethnicity officially. If the unofficial number is regarded as relevant, Transcarpathia has very likely the largest Roma population in Ukraine. Most Roma settle in the Hungarian-speaking area nearby the Hungarian border and use to speak Hungarian.

The $0.5 \%$ or 5,600 Slovaks live in some smaller settlements near to the Slovakian border.

The $0.3 \%$ or 3,500 Germans are only the small remnants (about $1 / 4$ ) of the much larger German group counted in 1941. They were significantly reduced by deportation and emigration at the end and after World War II. Since then their number remained relatively stable. They are scattered over some ethnic islands.

In 2001 less than 3,000 Jews lived in Transcarpathia, while they were the $3^{\text {rd }}$-largest group up to World War II. They were dramatically reduced by the Holocaust, after 1945 they lost by emigration to Israel and the United States. As in the past they are mainly urban dwellers.

A sociological investigation as of 1994 on inter-ethnic relations between ethnic groups resulted a.o. in the findings that Ukrainians, Rusyns, Slovaks, Hungarians and Russians accept each other rather well, while Jews, Romanians, Moldavians and especially Roma are less integrated (Jordan \& Klemenčić, 2004a, Fig. 20, p. 292).

\section{ECONOMIC POTENTIALS AND PERSPECTIVES}

As already mentioned Transcarpathia is an economic periphery even within economically weak Ukraine (see also Kocsis, Rudenko \& Schweitzer, 2008). Economic potentials are therefore not so much to be found in highly developed industrial products and specialized services (typical rather for central regions), but in taking

\footnotetext{
${ }^{4}$ Rusyn has, however, been standardised in Slovakia as well as in the Serbian Voivodina [Vojvodina], but in diffferent ways.
}

advantage of its (1) natural potentials, (2) location in international transportation networks, (3) multiethnic structure and basically Central European character.

\subsection{Natural potentials}

As regards natural potentials, forests stand out. $60 \%$ of the area are covered by wood which can be and is used for timber production and timber processing industries. Another asset are pleasant landscape and mineral waters. Especially Transcarpathia's share in the Carpathians is touristically attractive. The Ukrainian Carpathians rise up to an altitude of 2061 metres (Goverla), are at higher altitudes covered by alpine graslands, but have otherwise dense wood cover. Svaljava, Sinjak, Poljana, Sojmi or Ust'-Čorna are more prominent sources of mineral waters and health resorts - sometimes with an attractive built environment inherited from the pre-World War I period. However, even compared to its closer vicinity (eastern Slovakia, Romanian Maramureş, northeastern Hungary) Transcarpathia's touristic attractivity is not overwhelmming (Jordan, Schappelwein \& et al., 1999). It can attract tourists from Ukraine and East Central Europe; due to its multicultural structure and its German ethnic islands it has also some potential for ethnic and „sentimental“" tourism (like Transylvania [Ardeal] in Romania or Spiš in Slovakia). But this would need additional investment into tourist infrastructure, the development of a service mentality and the reduction (or even better: abolition) of the existing border bureaucracy. Taking into account the extremely and globally competitive tourism market it is hard to imagine that Transcarpathia will even then succeed to attract a larger number of tourists from Europe's main generating markets, i.e. Germany, Netherlands, United Kingdom, France, Italy.

\subsection{Location in international transportation networks}

In road and railway traffic Transcarpathia is located at Corridor V of the (multimodally defined) trans-European transportation networks (TEN-T). This Corridor connects ports of the northern Adriatic across the Pannonian Basin with L'viv, where it converges with Corridor III. In Transcarpathia Branch A of this Corridor converges with the main track of Corridor V.

This Corridor could be used as a location asset for the regional economy. But roads are only partly upgraded yet. This is true mainly for Hungary, in closer vicinity of the Ukrainian border especially for the Hungarian Motorway No. 3 from Budapest to Nyiregyháza, and for the road across the Carpathians. The rigid border regime constitutes an even harder obstacle for a rise of transportation frequency.

It is also a question, whether traffic tension between the Ukraine and the Pannonian Basin and the Northern Adriatic will ever be strong enough to create more intensive transportation flows. This will very much depend on the Ukraine's integration into European economic structures. But even then Black Sea ports as well as ports at the Baltic Sea will always be strong in competing with the ports of the Northern Adriatic for Ukrainian cargo.

For railway transportation the change of tracks at the Ukrainian border is an additional time-consuming obstacle.

As regards gas and oil pipelines, in Transcarpathia several European pipelines are converging. Oil is transported by "Druzhba I" and "Druzhba II" as well as 
"Southern Druzhba", gas by "Brotherhood [Bratstvo]" and "Soyuz" (Kocsis, Rudenko \& Schweitzer, 2008, p. 110). An additional gas line is planned.

But the region's benefits from being crossed by pipelines are not very significant in a politically and economically centralised system like the Ukraine. Such benefits are mainly consumed in the phase of construction and (less) by maintainance.

\subsection{Multiethnic structure and basically Central European character}

Transcarpathia's multiethnic structure as well as its basically Central European character may very well be regarded (also) as economic potentials.

Multiethnic structure implies a multitude of language skills and other cultural abilities which can be well applied on the labour market.

Being (besides Galicia and Bucovina) the only „Central European" part of Ukraine is at least an additional argument for investors from Central Europe. They look for „cultural affinity“ and make it very often the differentia specifica with investment decisions, when other conditions like wage level, access to raw materials, access to markets, location in the transportation network are also acceptable.

"Central Europe" is in this context not a vague concept, but filled with very explicit contents relevant for productivity such as working ethos, to be in time, strict observation of agreements. Investors attribute them in ethnically mixed regions also to cultural groups, who are not regarded as Central European in the narrower sense (as Germans or Hungarians are), but relate them to a region in total. This can be concluded from interviews conducted by Berenike Ecker (2005) in Transcarpathia and Mihály Szábo (2008) in Transylvania with heads and leading employees of enterprises based on foreign direct investment (FDI).

\section{HOW WERE THE POTENTIALS USED SO FAR?}

Transcarpathia's relative position among Ukrainian regions has improved in the transformation period. This shows itself, e.g., in a positive population development, for which a positive migration balance is the main reason (Kocsis, Rudenko \& Schweitzer, 2008; Ecker, 2005).

\subsection{Industrialisation}

This improvement is first of all due to successful industrialisation mainly in wood processing and food production by Joint Ventures and FDI.

Leading enterprises in wood processing are (Ecker, 2005, p. 89) Eno-Mebli, a Ukrainian-Austrian joint venture in Mukačeve producing furniture; Fischer, an Austrian producer of skies and other sports equipment in Mukačeve; Sten Ltd., a Swedish timber producer in Mižgir'ja; Proza Ltd., a Ukrainian-Swedish timber and furniture producer in the districit [rajon] Rahiv.

All the leading enterprises in food production are owned by Ukrainians, but smaller wine producers and friut processors around Beregove/Beregszász and Vínogradív are FDI-based (Ecker, 2005).

In March 2001 a Special Economic Zone (SEZ) has been established along the Hungarian border with some islands in the hinterland (e.g. Mukačeve). It attracted mainly electrotechnical industry, but has also detrimental effects in economic terms: It results in less tax revenues, the infrastructure has in fact to be paid by enterprises outside the SEZ, other areas receive less investment (Ecker, 2005).

Besides, for Transcarpathia in total a special investment regime exists. It is bound to permits, issued by local and regional civil officers. This, however, is almost an invitation for corruption, which is anyway widespread and a major obstacle for FDI all over Ukraine.

All these factors combined resulted in a rather high industrial density - even compared to other parts of the Ukraine (Kocsis, Rudenko \& Schweitzer, 2008, Fig. 55, pp. 102-103). Wood processing, food industry and electrochemical as well as electronic industry are the dominating branches.

\subsection{The Hungarian minority}

A second development factor are the Hungarians in Transcarpathia and their relations to Hungary. As already mentioned they reside along the Hungarian border, are also after Hungary's Schengen accession allowed to pass the border just by presenting an identity card, commute for work to Hungary and earn there well, more than the average population. Hungarian enterprises invest preferably in the Hungarian part of Transcarpathia. Hungarians in Transcarpathia are supported by the Hungarian state as regards cultural activities and education.

\subsection{Unexploited potentials}

In spite of some progress several potentials remained unexploited.

Perhaps the first to mention is agriculture. It was privatized only with strong delay (since 1999) by restitution to former owners and their heirs (Barisitz, 2001; CramonTaubadel \& Striewe, 1999). This meant in most cases the subdivision of large collective enterprises into small plots, which are cultivated only for subsistance or not at all. Market production almost collapsed, fallows especially in the Carpathian forelands (not so much in the Lowland) appeared.

This does, however, not apply to the mountain region, where traditional small-scale farming had persisted throughout the Communist period escaping any attempt of collectivation. It is fully functional also today and based on well-balanced demographic structures. But the question arises how mountain farming can be maintained when transformation proceeds further and also the mountain population becomes increasingly exposed to the attractions of a fully effective market economy.

A second point is the Schengen regime, which on 21 December 2007 was expanded to Poland, Slovakia and Hungary - three of the four countries neighbouring Transcarpathia. Slovakia, however, had already in 2001 re-introduced the duty to have a visa for Ukrainians, which had a heavy impact on cross-border traffic flourishing in the 1990s.

With the exception of the Hungarian minority in Transcarpathia also Hungary's incorporation into the Schengen zone had its impact: small border traffic declined essentially.

Poland is not really relevant in this context, since its borders with Transcarpathia are short and affect a mountainous area. 
A third item is insufficient self-government at the regional level in Ukraine. Only at the local level (communes) all administrative bodies are elected. With regions [oblast'] and districts [rajon], however, elected councils are confronted with heads of the executive appointed by Kiev. The latter act on behalf of the central government in Kiev and are in fact politically stronger than the elected councils. This results in complicated decision processes, schematic solutions not adapted to regional needs, limited readiness for transborder cooperation and a lack of regional branding, for which these two regional levels would be responsible.

So it is up to mayors and communal administrations to be active, which is indeed and fortunately frequently the case (e.g. Mukačeve, Beregove/Beregszász).

\section{CONCLUSIONS}

Shaping by Hungarian history, borderland location and multiethnic structure can be defined as the essential components of Transcarpathian identity. Its economic potentials and prespectives rest mainly in richness in wood, Transcarpathia's pleasant landscape and mineral waters, its location in the European traffic network, its border location and bridge function, the rich language skills of its population, the region's Central European character.

By post-Communist industrialisation (wood processing, food industry, electrotechnical industry) and due to intense transborder relations of the Hungarian minority, the region was able to make some progress during the transformation period, but could not yet escape its economically peripheric position.

Major obstacles for a better development can be identified in an all but market-conform agriculture, in the Schengen regime cutting Transcarpathia off especially from Slovakia and Hungary as well as in Ukrainian regional governance structures enforcing centralist attitudes at the two levels of regional administration.

\section{BIBLIOGRAPHY}

Barisitz, St., 2001. Transcarpathia - Ukraine's Westernmost Region and a Gateway to Central and Western Europe. Focus on Transition, 2, pp. 77-96.

Bonkalo, A., 1990), The Rusyns. East European Monographs, Boulder, CO, New York.

Breu, J. (ed.) (1970-1989), Atlas of the Danubian Countries. Deuticke, Wien.

Breu, J., 1989, Language distribution. Atlas of the Danubian Countries. Deuticke, Wien, p. 231.

Česká akademie věd a uměni (ed.), 1935, Atlas Republiky Československé. Praha.

Cramon-Taubadel, S. von \& L. Striewe, (eds.), 1999, Die Transformation der Landwirtschaft in der Ukraine. Vauk, Kiel.

Deržavnyj komitet statystyky Ukraïni (ed.), 2003, Vseukraïn'skyj perepis naselennja '2001. http://www.ukrstat.gov.at (1 May 2013)

Deržavnyj komitet statystyky Zakarpats'ke oblasne upravlinnya (ed.), 1999, Administrativnyj $i$ teritorial'nyj podil ta naselennja Zakarpatskoi oblasti. Užgorod.
Ecker, B., 2005, Transkarpatiens ökonomische Entwicklung unter besonderer Berücksichtigung der außenwirtschaftlichen Bedeutungszunahme seit der Jahrtausendwende. Diploma work, University of Vienna.

Hokky, Ch., 1966, Ruthenia - Spearhead Toward the West. Danubian Research and Information Center, Gainsville, Florida.

Jordan, P.. Kocsis, K. \& et al., 2006, Ethnic Consciousness in Central and Southeast Europe around 2000. Atlas of Eastern and Southeastern Europe. Borntraeger, Stuttgart, 2.9-G9.

Jordan, P., Kappeler, A., Lukan, W. \& J. Vogl (eds.), 2001, Ukraine. Geographie - Ethnische Struktur - Geschichte - Sprache und Literatur - Kultur Politik - Bildung - Wirtschaft - Recht. Peter Lang, Wien, Frankfurt a.M., Berlin, Bern, Bruxelles, New York, Oxford.

Jordan, P. \& M. Klemenčić (eds.), 2004a, Transcarpathia - Bridgehead or Periphery? Geopolitical and Economic Aspects and Perspectives of a Ukrainian Region. Peter Lang, Wien.

Jordan, P. \& M. Klemenčić, 2004b, Transkarpatien Brückenkopf oder Peripherie? Geopolitische und wirtschaftliche Perspektiven einer ukrainischen Region angesichts der EU-Erweiterung. Europa Regional, pp. 189-202.

Kocsis, K., 1999, Kárpátalja mai területének etnikai térképe [1: 266.000]. MTA, Budapest.

Kocsis, K. \& E. Kocsis-Hodosi, 1998, Ethnic Geography of the Hungarian Minorities in the Carpathian Basin. Simon Publications, Budapest.

Kocsis, K., Rudenko, L. \& F. Schweitzer (ed.), 2008, Ukraine in Maps. MTA, Budapest.

Kozauer, N.J., 1964, The Carpatho-Ukraine between the Two World Wars - with Special Emphasis on the German Population. Thesis submitted to the Graduate School of Rutgers - the State University. New Brunswick, New Jersey.

Magocsi, P.R., 1978, The Shaping of a National Identity: Subcarpathian Rus', 1848-1948. Harvard University Press, Cambridge, Mass.

Magocsi, P.R., 1998, What can Europe learn from Transcarpathia? Inter-Ethnic Relations in Transcarpathian Ukraine. European Centre for Minority Issues, Kiel.

Magocsi, P.R., 1999a, A New Slavic Nationality? The Rusyns of East Central Europe. In: Focus on the Rusyns. Copenhagen, pp. 15-29.

Magocsi, P.R., 1999b, Of the Making of Nationalities There is No End. East European Monographs, New York.

Němec, F. \& V. Moudry, V., 1955, The Soviet Seizure of Subcarpathian Ruthenia. William B. Anderson, Toronto.

Panchuk, M., 1995, Political Rusynism in Ukraine. Political Thought, 2-3, pp. 232-238.

Rumpler, H. \& M. Seger, 2010, Soziale Strukturen (= Die Habsburgermonarchie 1848-1918, IX/2). Österreichische Akademie der Wissenschaften, Wien.

Szabó, M., 2008, Ethnizität als Standortfaktor. Investitionsverhalten von deutschen und österreichischen Unternehmen in Sibiu/Hermannstadt. Diploma work, University of Vienna. 